\title{
Analysis of Poultry Production and Marketing in Addis Ababa, Ethiopia: The Case of Small Scale Intensive Poultry Producers
}

\author{
Sena Amsalu \\ Department of Agricultural economics, Raya University, Ethiopia
}

\begin{abstract}
This article investigated the structure conduct and performance of poultry market and determinants of total sale value of poultry supply in Addis Ababa, using survey data 2017/18. To address these descriptive statistics and econometric models were employed. The study used the structure-conduct-performance model to determine the structure conduct and performance of poultry market and multiple linear regression econometric models to analyze determinants of poultry marketable supply. The data were generated by individual interview using pretested semi structured questionnaires and take a total of 100 farmers sample and 75 traders. This was supplemented by secondary data. Following the four firms' criteria of concentration ratio, Addis Ababa poultry market showed tight oligopolistic behavior in bird market and loss oligopoly in egg markets with 64.4 and 24.90 percent concentration ratio respectively. The maximum total gross marketing margin in bird and egg trading channel were about 53 and 41 percent respectively in channel XI and the highest producers share for bird and egg marketing were along producer- consumer. From OLS model sex, flock size, production cost and average lagged price of egg were found to affect total sale value of poultry significantly and positively, while distance to market affect poultry value negatively. The findings suggests that, effective market information service has to be established to provide accurate information on current poultry supply, in addition, emphasis should be given in reducing the level of oligopolistic nature of bird market and the government set strategies that improve competitiveness and efficiency of poultry market.
\end{abstract}

Keywords: poultry market; Structure conduct performance; Concentration ratio; marketing margin; oligopoly DOI: $10.7176 / \mathrm{JMCR} / 62-01$

Publication date: November $30^{\text {th }} 2019$

\section{Introduction}

Agriculture is the main economic activity in Ethiopia and more than $80 \%$ of Ethiopian population is dependent on agriculture of which livestock plays a very important role (Duguma et al., 2012). Livestock contributes about $20 \%$ of the GDP, supporting the livelihoods of $70 \%$ of the population and generating about $11 \%$ of annual export earnings (SPS-LMM, 2010). It is the source of many social and economic values such as food, draught power, fuel, cash income, security and investment in both the highlands and lowlands/pastoral farming systems (FDRE, 2010).

Poultry is the most important species for generating income for poor peri-urban, urban and rural households (Van, 2016). Now a day, the demand for eggs and poultry meat has significantly increased across large parts of the continent Africa including Ethiopia (WHO, 2010). It is estimated that the consumption of poultry meat and eggs will increase by $200 \%$ between 2010 and 2020 for at least some countries in Sub-Saharan Africa (USDA, 2013). To meet up the increasing demand, efficient marketing system is needed for availability of product supply at a fair price and to encourage higher production (Omar et al., 2013).

Marketing is an important aspect of any livestock production system. It provides the mechanism whereby producers exchange their livestock and livestock product for cash. The cash is used for acquiring goods and services which they do not produce themselves, in order to satisfy a variety of needs ranging from food items, clothing, medication, and schooling to the purchase of breeding stock and other production inputs and supplies (Alemu, 2010).

Urban poultry production, consisting of a large number of small scale farms, and a few medium to large scale poultry farms, is concentrated mainly in and around the major towns of the country like Addis Ababa, Bishoftu and Adama areas (Vernooij et al., 2012). In order to obtain the required benefit from untapped potential of the poultry sector through commercializing, marketing skills need to be further developed, based on additional market research works

\subsection{Statement of the Problem}

Ethiopia ranks first in Africa and tenth in the worldwide with respect to the livestock population. However, there are a number of fundamental constraints underlie these outcomes. These include poor marketing infrastructure, lack of marketing support service, lack of market information traditional technologies, limited supply of inputs (feed, breed, stock, water), poor or non-existent of extension service, high diseases prevalence, and limited credit services affect the livestock marketing conditions (Berhanu et al., 2010).

Livestock products particularly poultry products have sky rocketing demand throughout the world. It is 
widely recognized that an inefficient marketing system entailing substantial costs to consumers and less incentives to producers could not provide the mechanism to meet the accelerating demand for high quality food items (Fafchamps, 2014). Similarly in the capital of Ethiopia, Addis Ababa, there are high demands and potentials of poultry products but, low marketing performances (Azage n.d.).

According to USDA (2017) report in Addis Ababa there are cyclical demands for poultry product and fluctuation in number of exotic chicken supplied to the market as compared to the high potential of the subsector in the country. In addition to these the age of the poultry farmer, family size, educational level and farming experience of the poultry farmers significantly affects the number of birds kept by the poultry farmer (Nebyu, 2016). Thus, poultry market requires critical evaluation of the existing poultry marketing system and identifying determinants of total sales value, in order to have a sustainable benefit and proper functioning of marketing actors.

Past research works in Ethiopia conducted mainly in rural part of Ethiopia (Mekonin, 2007, Awol, 2010, Dawit, 2010, Meseret, 2010 and Thilahun 2013) and some researches were also conducted in Addis, which was largely concentrated on impacts of HPAI (high pathogenic avian influenza) on poultry value chain actors, on exotic egg product market and waste management system (Gezahegn, 2010, Azage et al., n.d. and Nebyu et al., 2016). However, little has been said on marketing efficiency.

\subsection{Objective of the Study}

The general objective of this study was to analyze poultry production and marketing in Addis Ababa, Ethiopia. The specific objectives were:

1. To show the poultry marketing structure, conduct and performance of the study area.

2. To identify factors that determine poultry supplied to the market in the study area.

\section{MATERIALS AND METHODS}

\subsection{Description of the Study Area}

The study was conducted in Addis Ababa, Ethiopian. Administratively, the City is having three layers of government: City government, Sub-city administrations, and District (Woreda) administrations. The City has divided into 10 sub-city administrations. Addis Ababa is situated at a latitude of 90 3' North and 380 43' East and an altitude of 2408 meters above sea level. The total human population was estimated to be $3,273,000$ consisting 1,583,000 men and 1,690,000 women with 3.8\% annual growth rate (CSA, 2013). 16,602 numbers of people in the city were engaged in agriculture. The city dwellers participate in cultivation of gardens and in animal husbandry including poultry. The poultry population in Addis Ababa is about 350,000 where most of the chicken is raised on small scale level in the backyards.

\subsection{Data Sources and Methods of Data Collection}

For this study both primary and secondary data sources were used. Primary data was collected from samples of the respondents using two types of semi-structured questionnaires develop both for the smallholder farmers and for traders. Secondary data were collected from different sources.

\subsection{Sample Size and Procedure}

The urban poultry farmers were selected using a two-stage sampling technique. The first stage involve purposive selection of five sub-cities out of the ten sub-cities based on the practice and the availability of small scale intensive poultry farms in those areas. Accordingly, Gullele, Bole, Nifasilk-lafto, Akaki-kality and Yeka subcities were selected for this study. In the second stage, small scale intensive urban poultry farmers were listed in consultation with the respective sub-cities urban agriculture experts and selected randomly from the list of urban poultry farmers from each select sub-city. The sample size $(\mathrm{N})$ was determined using the formula recommended by (Arsham, 2007) to obtain a sample size of 100 small scale intensive urban poultry farmers with the assumption of 5\% SE. The marketing information was also collected randomly selected 27 and 48 market participants (traders) in chicken and egg markets respectively and the choice of them is based informal discussions with key informants in the marketing system.

$\mathrm{N}=0.25 / \mathrm{SE}^{2}$

Where: N: number of sample, SE: standard error 
Table 1 Sample size distribution among selected sub city of the study area

\begin{tabular}{lccc}
\hline Sub-city & Small scale poultry farmers & Proportion to Total & Actual sample size \\
\hline & $(\mathbf{N})$ & & 21 \\
Gullele & 124 & 0.21 & 17 \\
Bole & 102 & 0.17 & 22 \\
Nifasilk-Lafto & 130 & 0.22 & 24 \\
Akaki-Kality & 140 & 0.24 & 16 \\
Yeka & 98 & 0.16 & 100 \\
Total & 594 & & \\
\hline
\end{tabular}

\subsection{Methods of Data Analysis}

3.4.1. Descriptive statistics

Market Structure: This study adopted concentration measure (CR) to analyze the degree of trader's concentration in sample market places in performing the exchange function.

$\boldsymbol{C R}=\sum_{i=1}^{r} S i$

Where

$\mathrm{C}=$ is concentration ratio, $\mathrm{Si}=$ is the percentage share of the all firms and $\mathrm{r}=$ the number of the largest firms for which the ratio is to calculated.

Kohls and Uhl, (1985) bring into play as a rule of thumb, four largest enterprises' concentration ratio of $50 \%$ or more (an indication of a strongly oligopolistic industry), 33-50\% (a weak oligopoly) and less than that (competitive industry).

Market conduct: Meijer, (1994) said that, "conduct is pattern of behavior which enterprises follow in adopting or adjusting to the market in which they sell or buy", in other words the strategies of the actors operating in the market. It is a systematic way to detect indication of unfair price setting practices and the conditions under which practices are likely to prevail. In this study market conduct were analyzed in terms availability of market information.

Market performance: The performance of an industry for a particular commodity can be evaluated in terms of technical and pricing efficiency. Marketing costs and marketing margins, influences on consumption, distribution and market access are best efficiency parameters to analyze the performance of a market.

Marketing margin: -Marketing margin was calculated taking the difference between producers and retail prices. The producers' share is the commonly employed ratio calculated mathematically as, the ratio of producers' price (ex-vessel) to consumers' price (retail) (Mendoza, 1995).

$P S=\frac{P_{X}}{P_{r}}=1-\frac{M M}{P_{r}} \ldots \ldots \ldots \ldots \ldots$

Where; $\mathrm{PS}=$ producer share

$\mathrm{P}_{\mathrm{x}}=$ producers' price of poultry

$\mathrm{P}_{\mathrm{r}}=$ retail price of poultry product which is consumer price of poultry

$\mathrm{MM}=$ marketing margin

Total marketing margin:- Computing the total gross marketing margin (TGMM) is always related to the final price paid by the end buyer and is expressed as percentage (Mendoza, 1995).

$T G M M=\frac{\text { Consumer price }- \text { Farmers price }}{\text { Concumer price }} \times 100$

Where TGMM= Total gross marketing margin

Net Marketing Margin (NMM):- Is the percentage over the final price earned by the intermediary as his net income once his marketing costs are deducted. (ibid).

$N M M=\frac{\text { Gross Margin }- \text { Marketing Cost }}{\text { Consumer Price }}$

Market cost:- This include handling cost, transportation cost, production loss, storage cost, processing cost, capital cost, commission and other unofficial payments. Marketing costs and marketing margins, influences on consumption and distribution (Holloway and Ehui, 2002).

\subsubsection{Econometric analysis}

Following Green (2003), the multiple linear regression models is specified as $\mathrm{Yi}=\mathrm{F}$ (price, poultry output, access to extension services, education level, experience, sex, access to credit, age, etc...). The econometric model specification of supply function in matrix notation is estimated by 
$Y=\beta X+U$

Where $\mathrm{Yi}=$ total sale value from poultry marketing

$\beta=$ a vector of estimated coefficient of the explanatory variables

$\mathrm{X}=\mathrm{a}$ vector of explanatory variables

$\mathrm{Ui}=$ disturbance term (price, poultry output, access to market information, access to extension services, education level, experience, sex, access to credit, age, etc)

\section{RESULTS AND DISCUSON}

\subsection{Structure, Conduct and Performance of Poultry Marketing System}

\subsubsection{Poultry market structure}

The degree of market concentration ratio was used to evaluate the structure of chicken market. Four traders with the largest volume of chicken handled were used for the calculation at main poultry market places (Table 2)

Table 2 Chicken trader's concentration ratio

\begin{tabular}{cccccc}
\hline Number of traders & Cumulative frequency & Number handled & $\begin{array}{c}\text { Total } \\
\text { number }\end{array}$ & $\begin{array}{c}\text { Market share } \\
(\mathrm{Si})\end{array}$ & \\
& & & & \\
$C R=\sum_{i=1}^{4} S i$
\end{tabular}

Source: Own computation (2018)

The results showed that the concentration ratio of poultry market in Addis market was $33.7 \%$ and this figure suggested that the market type is loose oligopoly market type. This is to mean the top four traders are controlling only 33.7 percent of the chicken market.

As can be seen from Table 3, the four firms' market concentration ratio for egg market was calculated and it was found to be $28.6 \%$, which implies that the market type is loose oligopoly. These less concentration ratios of egg market happened mainly because the poultry market transaction involved too many suppliers including large number of farmers directly selling their product to the final consumers. The poultry market in the study area is identified to have competitive market nature. It was also found to be less buyer's concentration. Hence, it is possible to conclude that egg market in Addis display the character of competitive market. The result indicated the relative competitiveness of the market. 
Table 3 Egg trader concentration ratio

\begin{tabular}{cccccc}
\hline Number of traders & Cumulative frequency & Number handled & Total number & $\begin{array}{c}\text { Market } \\
\text { share } \\
(\mathrm{Si})\end{array}$ & $C R=\sum_{i=1}^{4} S i$ \\
\hline 1 & 1 & & 9.6 & 9.6 \\
3 & 4 & 444,000 & 444,000 & 19 & 28.6 \\
1 & 5 & 289600 & 868,800 & 5 & 43.6 \\
2 & 7 & 240,000 & 240,000 & 46.6 \\
1 & 8 & 232,600 & 465,200 & 10 & 48.6 \\
1 & 9 & 216,000 & 216,000 & 5 & 56.6 \\
1 & 10 & 180,000 & 180,000 & 4 & 75.4 \\
7 & 17 & 180,000 & 180,000 & 4 & 77.4 \\
1 & 18 & 126,086 & 882,600 & 18.8 & 79.4 \\
1 & 19 & 96,000 & 96,000 & 2 & 83.4 \\
2 & 21 & 84,000 & 84,000 & 2 & 86.4 \\
2 & 23 & 84,000 & 168,000 & 4 & 88.4 \\
1 & 24 & 75,000 & 150,000 & 3 & 89.4 \\
1 & 25 & 72,000 & 72,000 & 2 & 90.4 \\
7 & 26 & 60,000 & 60,000 & 1 & 95.4 \\
1 & 33 & 56,000 & 56,000 & 1 & 95.9 \\
1 & 34 & 33,171 & 232,200 & 5 & 99.5 \\
2 & 45 & 25,000 & 25,000 & 0.5 & 99.6 \\
& 46 & 14,957 & 164,524 & 3.6 & 100
\end{tabular}

Source: Own computation (2018)

\section{Condition of entry and exit to live bird and egg trading}

The barriers to entry is something that blocks or impedes the ability of the traders to enter into the market and the barriers to exit is something that blocks or impedes the ability of the traders to leave the market. Poultry traders in Addis Ababa have entry barrier due to licensing procedure, associated cost incurred, information access, and price and demand fluctuation. In addition, poultry market participation startup capital or credit requirements are the other pre-supposed entry barriers since participation in poultry market require an individual to allocate starting up capital which range between 1500 ETB to 75000 ETB for chicken trader and range between 1000 ETB to 77000 ETB for egg trader. The other entry barriers for chicken processors were quality of storage materials, the spice added to make it fresh, and packing materials were the main factor.

The other important factor that needs to be evaluated in the study of market structure is poultry market exit barrier. The finding of survey data reported that there is no requirement to meet by poultry traders. In addition to this most of the poultry traders did not have a fixed investment such as fixed shop and the like associated with marketing and hence, the traders simply went out of the market without qualifying any requirement, so it was possible to conclude that there was no any exit barrier of poultry marketing

\subsubsection{Market conduct}

Market conduct refers to the market behavior of all firms. In what way do they compete? Are they looking for new techniques and do they apply them as practicable? Are they looking for new investment opportunities, or are they disinvesting and transferring funds elsewhere? Market conduct also deals with the behavior of firms that are price searchers and are expected to act differently than those in a price-taker type of industry (Abbott and Makeham, 1981; Cramers and Jensen, 1982).In addition, market conduct is also refers to the practices or strategies of traders in maximizing their profits. The market conduct of traders in the subsector have been analyzed using information like selling and buying behaviors and price setting strategy of sample traders. According to the survey results, about 33.33, 11.11, 48.15 and 7.41 percent of chicken traders reported that purchase price was set by negotiation with the suppliers, by their own, suppliers and market respectively. With respect to egg trading, about $12.5,43.75,10.42$ and 33.33 percent of the sample traders reported that purchase price was set by their own, suppliers, the market and negotiation respectively. 
Table 4 Chickens and eggs traders market conduct

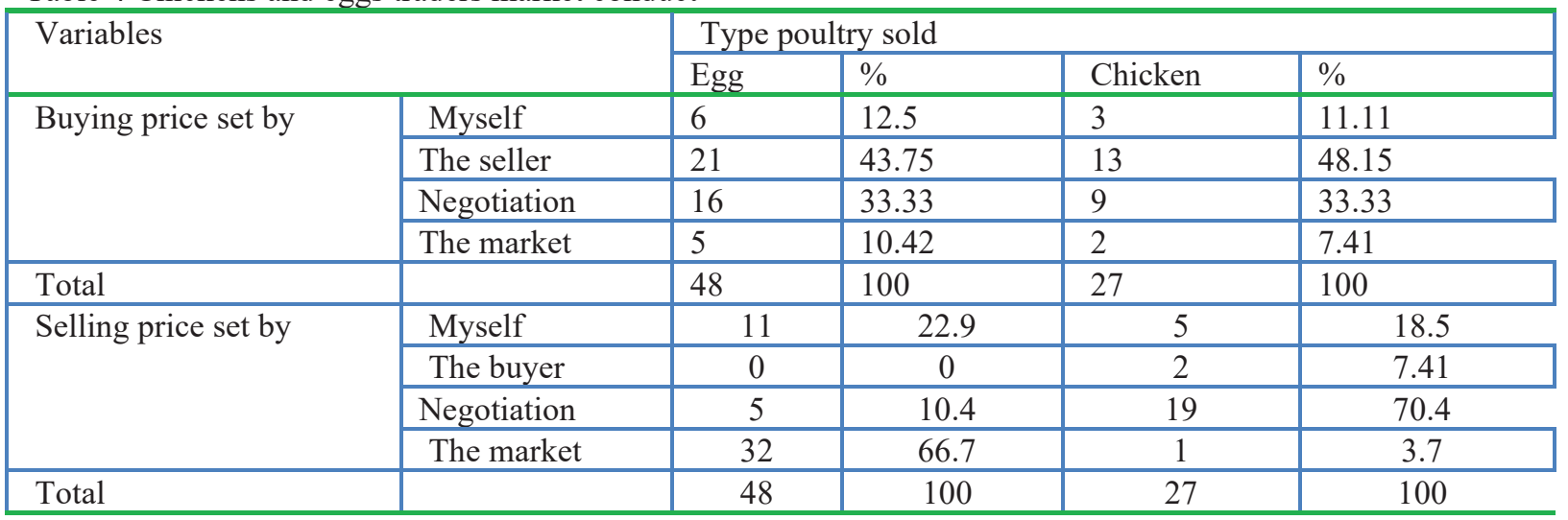

Source: Own computation (2018)

It was found that chicken weight; color and age to be used as a means of grading live chicken. In this respect, the demand for red feathered cock found to fetch higher price especially during holiday time mostly for New Year, Ethiopian Easter and Christmas however, color matter little for those purchased for hotel, regular consumers and Muslim consumers. The age of a cock also found to be one of the factors determining the price of the cock and hen and it was determined by looking at the cock leg and feather of hens; older age found to negatively influence the price of cock and hen in Addis market. With respect to eggs market, it was found that there was no standard grade for eggs, however, small verses big eggs and local against exotic eggs sold relatively slight price difference. On the other hand, physically damaged and spoiled eggs usually end up priceless. Spoiled egg usually screened through eye check method.

Provision of better price than others and use of strong negotiation word power and various combinations of these two strategies are applied by most bird and egg traders to attract buyers and sellers. Regarding product differentiation, very few actors involved in processing function add values to alter the type of the product they serve for consumers.

Unlike bird trading, the price setting strategy in egg market is better in terms of price setting and information access. The price of egg is not that much volatile as in observed in live bird trading. According to the finding of the market survey, the price of egg is set earlier in the market day based on the price information in the some market. There are no significant variations in egg traders' response regarding egg traders' marketing behaviors (conduct measures) among the sample respondents as in observed by live bird marketing participants.

\subsubsection{Performance of poultry marketing system}

Marketing performance is calculated in terms of cost and margin for the following actors and marketing channels. Chicken Marketing Channels

Channel I Framers $\longrightarrow$ Consumers $(2 \%)$

$$
\begin{aligned}
& \text { Channel II Farmers } \longrightarrow \text { Retailers } \longrightarrow \text { Consumers }(11 \%) \\
& \text { Channel III Farmers } \longrightarrow \text { Urban collectors } \longrightarrow \text { Retailers } \longrightarrow \text { Consumers }(18 \%) \\
& \text { Channel IV Farmers } \longrightarrow \text { Urban collectors } \longrightarrow \text { Consumers }(5 \%) \\
& \text { Channel V Farmers } \longrightarrow \text { Urban collectors } \longrightarrow \text { Processors } \longrightarrow \text { Consumer }(18 \%) \\
& \text { Channel VI Farmers } \longrightarrow \text { Processors } \longrightarrow \text { Consumers }(13 \%)
\end{aligned}
$$$$
\text { Channel VII Farmers } \longrightarrow \text { Rural traders } \longrightarrow \text { Urban assemblers } \longrightarrow \text { Consumers }(6 \%)
$$$$
\text { Channel VIII Farmers } \longrightarrow \text { Rural traders } \longrightarrow \text { Urban assemblers } \longrightarrow \text { Retailers } \gg \text { Consumers }(12 \%)
$$$$
\text { Channel IX Farmers Rural traders } \longrightarrow \text { Urban assemblers } \longrightarrow \text { processors } \longrightarrow \text { Consumers }
$$ 


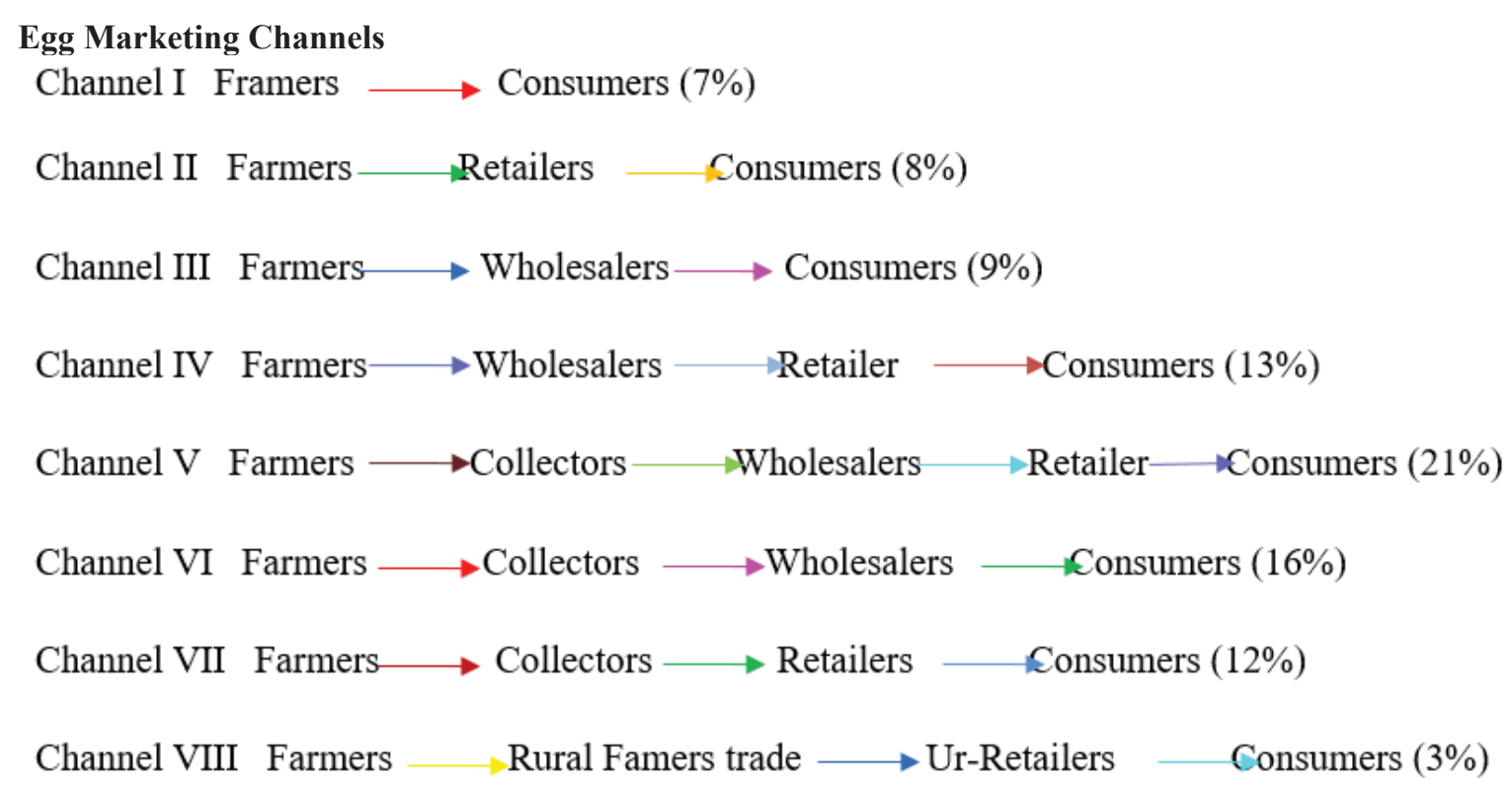

\section{Channel IX Farmers — Rural farmers traders $\longrightarrow$ Wholesalers $\longrightarrow$ Retailers $\longrightarrow$ Consumers $(6 \%$}

\section{Channel X Farmers $\longrightarrow$ Rural traders $\longrightarrow$ Wholesalers —Consumers (5\%)}

\section{Marketing costs of traders}

Information was collected on the various costs incurred in the process of assembling, transporting and selling poultry purchased. These costs outlays are referred to as marketing costs. The marketing cost of live bird and egg trading for varies marketing stages is calculated and depicted in Table 5 and 6 . In live bird trading the highest average marketing cost of varies trader category is registered by cost of chicken death, labor cost and distribution cost each costs $1.25 \mathrm{birr} / \mathrm{bird}, 1.2 \mathrm{birr} / \mathrm{bird}$, and $1.2 \mathrm{birr} / \mathrm{bird}$. The loss cost is mainly due to diseases. Feed and water cost, transportation costs, rent, and loan cost are worthwhile to be mentioned as they have significant contribution to the transaction cost involved in chicken trading. Urban assemblers and processors incur the highest marketing cost in bird trading business accounting 19.7 and 14.7 birr per bird respectively. The average transaction (marketing) cost in the flow of bird from the point of production to the final consumer is $9.5 \mathrm{birr} / \mathrm{bird}$. Table 5 Marketing cost of bird marketing system

\begin{tabular}{|c|c|c|c|c|c|c|}
\hline \multirow[t]{2}{*}{ Cost of marketing } & \multicolumn{6}{|c|}{ Agents } \\
\hline & $\begin{array}{l}\text { Urban } \\
\text { collectors }\end{array}$ & $\begin{array}{c}\text { Urban } \\
\text { assemblers }\end{array}$ & Processors & Retailers & $\begin{array}{l}\text { Rural } \\
\text { Trader }\end{array}$ & Mean \\
\hline Personal transport & 0.03 & 0 & 0 & 0.01 & 0.2 & 0.05 \\
\hline Feed and water cost & 0.17 & 2.5 & 0.1 & 0.7 & 0.5 & 0.8 \\
\hline Transportation cost & 0.08 & 1.2 & 0.23 & 0.09 & 0.09 & 0.34 \\
\hline Labor cost & 0.2 & 1.1 & 2 & 0.09 & 0.4 & 1.2 \\
\hline Distribution cost & 0.2 & 4.7 & 0.15 & 0.07 & 0.3 & 1.2 \\
\hline Overhead cost & 0.12 & 1.1 & 3 & 0.04 & 0.1 & 0.9 \\
\hline Cost of chicken death & 0.5 & 4.3 & 1 & 0.2 & 0.23 & 1.25 \\
\hline Tax and license cost & 0 & 0 & 2.8 & 0 & 0 & 0.6 \\
\hline Rent & 0 & 0.04 & 3.3 & 0.06 & 0.04 & 0.7 \\
\hline Brokerage & 0 & 0 & 0 & 0 & 0.07 & 0.014 \\
\hline Loan & 0 & 0.3 & 1.2 & & 3.5 & 1 \\
\hline Telephone & 0.02 & 0.001 & 0.013 & 0.03 & 0.05 & 0.02 \\
\hline Cost of chicken/m & 1.02 & 2 & 0.85 & 0.09 & 1.2 & 0.82 \\
\hline Feed cost & 0.17 & 2.5 & 0.1 & 0.07 & 0.2 & 0.6 \\
\hline Total cost & 2.51 & 19.74 & 14.74 & 1.45 & 6.9 & 9.5 \\
\hline
\end{tabular}

Source: Own computation (2018) 
Table 6 revealed that the cost of pullet, loss cost and transportation cost constitute the greater portion of the total marketing cost of egg accounting $0.2 \mathrm{birr} / \mathrm{egg}, 0.1 \mathrm{birr} / \mathrm{egg}$, and $0.06 \mathrm{birr} / \mathrm{egg}$ each.

The average marketing cost in eggs trading in all traders category is about 0.57 birr per egg. Out of whom wholesalers, collectors and retailers incur the highest marketing cost in the flow of eggs from the point of production to the end users accounting $0.9,0.6$ and 0.5 birr per egg respectively. Higher marketing cost by actors in marketing channels reduces the relative competence of the marketing channel in the market chain.

Table 6 Marketing cost of egg marketing system

\begin{tabular}{llllll}
\hline Cost of marketing & Agents & & & & \\
& Urban collectors & Urban WS & Retailer & Rural traders & Mean \\
\hline Personal expense & 0.03 & 0.007 & 0.0032 & 0.014 & 0.014 \\
Transportation cost & 0.02 & 0.08 & 0.1 & 0.03 & 0.057 \\
Labor cost & 0.04 & 0.05 & 0.03 & 0.043 & 0.041 \\
Distribution cost & 0.03 & 0.05 & 0.04 & 0.021 & 0.035 \\
Overhead cost & 0.02 & 0.02 & 0.06 & 0.01 & 0.028 \\
Loss & 0.05 & 0.2 & 0.08 & 0.09 & 0.105 \\
Rent & 0.004 & 0.04 & 0.003 & 0 & 0.012 \\
Brokerage & 0.006 & 0.003 & 0.001 & 0.08 & 0.023 \\
Egg handling & 0.05 & 0.04 & 0.035 & 0.005 & 0.033 \\
Telephone & 0.06 & 0.004 & 0.002 & 0.01 & 0.019 \\
Cost of egg & 0.3 & 0.4 & 0.1 & 0.01 & 0.203 \\
Total cost & 0.61 & 0.89 & 0.45 & 0.31 & 0.57 \\
\hline
\end{tabular}

Source: Own computation (2018)

\section{Marketing margins in bird and egg marketing chain}

Marketing margin is the percentage of the final weighted average selling price taken by each of the marketing chain. The margin must cover the cost involved from one stage to the next and provide a reasonable return to those doing the marketing. Marketing costs and margins were calculated for main agents in the marketing channel such retailers, collectors, assemblers, processors, wholesalers and rural traders. Table 7 summarizes marketing margins maintained by each actors in varies bird and egg marketing channels.

Total gross marketing margin in bird trading is highest in channels, IX, VI, V, VIII and VI they account a TGMM of $53.12 \%, 51.9 \%, 50.9 \%, 47 \%$ and $44.44 \%$, of the consumers' price. Processors enjoy the highest net marketing margin that is $47.6 \%$ in channel VI followed by urban collectors, urban assemblers and retailers maintain a NMM of $29.7 \%, 26.5 \%$ and $20.8 \%$ in channel IV, VIII, and II. Producers share from the price paid by consumers is highest in channel I, which accounts $100 \%$ of consumer's price, followed by channel II and channel IV which accounts $78.7 \%$ and $70.7 \%$ of the price paid by consumers. The lowest net marketing margin is associated with rural traders in channel VII, VIII, and X of bird marketing chain.

Table 7 Marketing margin maintained by marketing actors in bird and egg marketing chain

\begin{tabular}{|c|c|c|c|c|c|c|c|c|c|c|}
\hline Bird trader & I & II & III & IV & V & VI & VII & VIII & IX & $X$ \\
\hline TGMM & & 21.3 & 34.6 & 29.3 & 50.9 & 51.9 & 44.44 & 47 & 53.12 & \\
\hline NMMcol & & & 28.32 & 29.7 & 27.4 & & & & & \\
\hline NMMas & & & & & & & 25.1 & 26.5 & 26.1 & \\
\hline NMMp & & & & & 27.4 & 47.6 & & & 14.15 & \\
\hline NMMret & & 20.8 & 6.9 & & & & & & 5.5 & \\
\hline NMMrutr & & & & & & & 14 & 14 & 14 & \\
\hline GMMp & & 78.7 & 65.4 & 70.7 & 49.1 & 48.1 & 55.6 & 53 & 46.9 & \\
\hline \multicolumn{11}{|l|}{ Egg traders } \\
\hline TGMM & & 33.33 & 28.20 & 30 & 38 & 29.9 & 32.5 & 37.5 & 41.18 & 36.70 \\
\hline NMMrt & & 23.33 & & 10 & 2.3 & & 1.25 & 7.5 & 2.35 & \\
\hline NMMws & & & 10.26 & 6.67 & 3.85 & 1.30 & & & 1.27 & 1.27 \\
\hline NMMcol & & & & & 9.32 & 9.32 & 9.32 & & & \\
\hline NMMrur & & & & & & & & 13.54 & 6.33 & 6.33 \\
\hline GMMp & & 66.67 & 71.80 & 70 & 62 & 70.1 & 67.50 & 62.5 & 58.82 & 63.30 \\
\hline
\end{tabular}

Source: Own computation (2018)

The highest producer share is observed in channel III of egg marketing chain that is $71.8 \%$ out of the price paid by consumers. The highest net marketing margin in egg marketing chain is observed in channel II by the retailers that is $23.33 \%$. The lowest net marketing margin in egg marketing chain is observed in channel VI and $\mathrm{X}$ that accounts $1.3 \%$ each and this is maintained wholesaler. The marketing margin analysis of the subsector revealed that producers share and net marketing margin maintained by varies chain actors are remarkably varied 
across the different marketing channels.

\subsection{Results of Econometric Models}

In this respect, 15 variables were hypothesized to affect marketable surplus of poultry. Among these variables, only eight (8) variables namely (sex, credit access, extension access, distance to market, distance to agriculture office, lag price of chickens, flock size, and experience) were fit the model. Multiple linear regression models were employed to identify the factors. Multicolliniarity and heteroscedasticity detection test were performed and the result shows that there is no multicollinearity problem.

Table 8 Result of OLS model

Linear regression

$\begin{array}{lr}\text { Number of obs } & =100 \\ \text { F } 15, \quad 84) & =11.50 \\ \text { Prob }>\text { F } & =0.0000 \\ \text { R-squared } & =0.5617 \\ \text { Root MSE } & =17613\end{array}$

\begin{tabular}{|c|c|c|c|c|c|c|}
\hline TSV & Coef. & $\begin{array}{l}\text { Robust } \\
\text { Std. Err. }\end{array}$ & $t$ & $P>|t|$ & [95\% Conf. & Interval] \\
\hline sex & 8898.261 & 3458.669 & 2.57 & 0.012 & 2020.32 & 15776.2 \\
\hline age & 181.9401 & 200.0597 & 0.91 & 0.366 & -215.9006 & 579.7808 \\
\hline familysize & -128.1669 & 1284.501 & -0.10 & 0.921 & -2682.538 & 2426.205 \\
\hline educ & 1194.234 & 1830.722 & 0.65 & 0.516 & -2446.356 & 4834.825 \\
\hline offincome & -.0565972 & .1198264 & -0.47 & 0.638 & -.2948851 & 1816907 \\
\hline experrrr & -2889.054 & 2648.007 & -1.09 & 0.278 & -8154.906 & 2376.799 \\
\hline landholding & -107.5794 & 81.91561 & -1.31 & 0.193 & -270.4776 & 55.31877 \\
\hline distmkt & -3642.845 & 2137.722 & -1.70 & 0.092 & -7893.939 & 608.2492 \\
\hline distagriof e & -679.3144 & 696.1708 & -0.98 & 0.332 & -2063.726 & 705.0976 \\
\hline lagpriceegg & 4990.514 & 1400.281 & 3.56 & 0.001 & 2205.903 & 7775.126 \\
\hline lagpricech $\sim n$ & 4.134198 & 14.93173 & 0.28 & 0.783 & -25.55919 & 33.82758 \\
\hline production t & .0552481 & .0296714 & 1.86 & 0.066 & -.0037566 & .1142529 \\
\hline acessexten & -5026.582 & 3839.388 & -1.31 & 0.194 & -12661.63 & 2608.462 \\
\hline flocksize & 86.20247 & 18.35347 & 4.70 & 0.000 & 49.70459 & 122.7004 \\
\hline credit & -10532.04 & 3631.066 & -2.90 & 0.005 & -17752.82 & -3311.268 \\
\hline _cons & 6920.958 & 18093.09 & 0.38 & 0.703 & -29059.15 & 42901.06 \\
\hline
\end{tabular}

Sex (SEX): Sex of the house hold head significantly $(\mathrm{p}<0.01)$ and positively affects total sale value. Female headed households in the observation attain about 1.94 birr additional income from the sale of chickens and eggs to the market.

Distance to woreda market as expected it influences marketable of poultry negatively and statistically significant at $(\mathrm{p}<0.1)$ significance level. This means as the distance to woreda market increases by one kilometer the probability to participate in poultry market decreases total sale value by 3642.845 .

Average lagged price of egg (AVLAGPR egg): The average lagged price of egg influence the value obtained from the sale of live birds and egg significantly $(\mathrm{p}<0.01)$ and positively. An increase in the average lagged price of egg by one birr the value obtained from the supply of egg to the market increases by 4990.514 amounts.

Production cost (PC): production cost here unexpectedly affect total sale value positively which means for each additional cost of production, total sale value of poultry is predicted to increase by 0.055 units, and this association is statistically significant $(p=0.1)$. This shows that as the cost of production increase farmers supply more of poultry to the market in this way they could cover the production cost.

Flock size (FLOCKSIZE): As it was hypothesized the size of poultry heard in the household was found to positively and significantly influence total sale value of poultry product at $(\mathrm{p}<0.01)$ significant level. As expected that a unit increase in poultry number would result total sale value of poultry increase by 86.20 birr. Similar to the finding of this study Nebyu, (2016) indicated that size of herd was significant factor determining smallholder's income from poultry product. The study result is also similar with the result of Dawit (2010) which indicated that poultry size is positively related to the value earn poultry sale. 
Credit access (CA): Credit use by the sample respondents significantly $(p<0.05)$ and negatively affects the value obtained from the supply of live birds and egg to the market. The value obtained from the sale of chickens and eggs for sample respondents who access credit has decrease by birr 10532.04 than those who do not access credit. These investigations bring the opposite result with investigation of Awol, 2010, Tilahun, 2013 and Azage, 2002. Credit access expected to bring positive result but here access to credit affect total sale value negatively and this is justified as when the amount of credit and the duration of payment raise the interest rate could raise this may bring crises to farmers future business since they expected to pay the amount they get from sale.

\section{CONCLUSIONS AND RECOMENDATIONS}

\subsection{Conclusions}

Several intermediaries are involved in poultry marketing at different levels. Producers, wholesalers, collectors, assemblers, rural traders, processors and retailers are all identified poultry market role players.

Regarding the structure of live bird and egg marketing system in Addis (wereda) show that marketing systems are fairly concentrated in terms of few firms' domination. Lack of information on price, supply and demand, low or lack of financial access, high startup capital, color of poultry hold, types of eggs and short and inconsistent supply of live bird and egg are among the most influential entry barriers in all sample markets mentioned by sample traders. This indicating that how the existing structure of marketing system affects the conduct of marketing actors and hence the performance of the entire marketing system. Thus there is a need to improve the marketing structure by creating competitive actors that involved in different value adding activities.

Cost of pullet, loss cost and transportation and distribution cost constitute the greater portion of the total marketing cost. Total gross marketing margin in bird trading is highest in channels, IX, accounts $53.12 \%$ of the consumers' price. Processors enjoy the highest net marketing margin that is $47.6 \%$ in channel. The lowest net marketing margin is associated with rural traders in channel VII, VIII, and X of bird marketing chain while, the highest net marketing margin in egg marketing chain is observed in channel II by the retailers that is $23.33 \%$. The lowest net marketing margin in egg marketing chain is observed in channel VI and X that accounts $1.3 \%$ each and this is maintained by wholesalers. This implying that there is no equal distribution of profits among traders. Therefore the performance of poultry market in Addis market is seems to be inefficient.

According to the econometrics analysis, the most important variables affecting the producers' value of live bird and egg supply were sex, credit access, flock size, distance to market, average lagged price of egg, and cost of production. These variables are found to be economically important variables in determining the volume of birds and eggs that the families supply to the market. Thus addressing these variables could help farmers by increasing total sale value.

Suggested future works include: There are different types of commercial poultry production in the area. However, due to time the study considered only the production of small scale intensive producers were selected. In the same way the study considered only five sub city. Hence there is a need of study which will consider 10 sub-cities. It is obvious that the poultry products' marketing system will be improved with better level of efficiency than the current level.

\section{REFERENCE}

Alemu A., 2010. Market chain analysis of red pepper: The Case of Bureworeda, West Gojjam zone, Amhara national regional state, Ethiopia. M.S.cThesis,Haramaya University, Ethiopia.

Arsham, H., Grad, J. and Jaklič, G., 2007. Perturbed matrix inversion with application to LP simplex method. Applied mathematics and computation, 188(1), pp.801-807.

Awol, Z., 2010. Analysis of Poultry Market Chain: The Case of Dale and Alaba „Speciale Woredas Of Snnprs(M.Sc. thesis Haramaya University, Ethiopia

Azage T., Berhanu G. and Dirk H., undated. Input Supply System and Services for Market-oriented Livestock Production in Ethiopia. IPMS Project, ILRI, Addis Ababa, Ethiopia.

Azage, T., Z sileshi, M. Tadesse and M.Alemayehu, 2002. Scoping study on urban and peri-urban livestock keeping practices in Addis Ababa. Part 1. Literature reveiew on dairy production management and marketin ILRI and EARO.

Berhanu Gebremedhin, H. Dirk and Samson Jemaneh. 2010. Heading towards commercialization? The case of live animal marketing in Ethiopia. Improving Productivity and Market Success (IPMS) of Ethiopian Farmers Project Working paper 5. ILRI (International Livestock Research Institute), Nairobi, Kenya. 73pp

Cramer, G. L. and Jensen, W., 1982. Agricultural Economics and Agribusiness, 2nd Edition McGraw Hill Book Company, USA. 222p.

CSA (Central Statistical Authority), 2015.Statistical report on socio-economic characterization of the population in agricultural households and land use part I A.A, Ethiopia.

Dawit Gebregziabher, 2010. Market chain analysis of poultry: the case of Alamata and Atsbi-WonbertaWoredas of TigrayRrgion, M.Sc. Thesis, Haramaya University, Ethiopia. 
Duguma R., 2012. Phenotypic characterization of some indigenous chicken ecotypes of Ethiopia. Livest. Res. Rural Dev., 18 (9). Available at www.cipav.org.co/lrrd/lrrd18/9/dugu18131.htm.

Fafchamps, M., Hill, R. and Kaudha, A., 2014. The transmission of international commodity prices to domestic producers (No. 0409038). EconWPA.

FDRE 2010. Ministry of Water Resources, National Meteorological Services Agency, pp: 1113.

Gebregziabher, D., 2010. Market chain analysis of poultry: the case of Alamata and Atsbi-wombertaWoredas of Tigray (Doctoral dissertation, Haramaya University).

Greene, W.H., 2003. Econometric Analysis, 5th Edition. Prentice Hall. Inc., London. 1026p.

Holloway, G. and Ehui, S., 2002. Expanding market participation among smallholder livestock producers,(Socioeconomics and Policy Research Working Paper 48; International Livestock Research Institute, Nairobi, Kenya). ILRI, Nairobi, Kenya, p.85.

Kohl, R.L. and Uhl, J.N., 1985. Marketing of agricultural product, fifth ed., Coiler Mac Milan, U.S.A.

Meijer, P.W.M., 1994. The function of maize market in Benin. Bert Broundjin, Benin, pp.11-32.

Mendoza, G., 1995. A primer on marketing channels and margins.In: Scott GJ (ed), Prices, products and people: Analyzing agricultural markets in developing countries. Lynne Reinner Publishers, Boulder, London, UK, pp.257-276.

Mekonnen Gebregziabher, 2007. Characterization of smallholder poultry production and marketing system of Dale, Wensho and Loka Abaya Werdas of southern Etthiopia. M.Sc. Thesis of Hawassa University, Ethiopia.

Meseret Molla, 2010. Characterization of village chicken production and marketing system in Gomma

Wereda, Jimma Zone, M.SC. Thesis Gimma University, Ethiopia.

Nebiyu Y., Berhan T. and Ashenafi M., 2016. Constraints, opportunities and socio-economic factors affecting flock size holding in small scale intensive urban poultry production in Addis Ababa, Ethiopia. Agriculture and Biology Journal of North America 3:146-152.

Nebiyu Y.A, 2016. Assessment Of Urban Poultry Production Practices In Addis Ababa With Emphasis On Egg Production, Product Marketing, Feed Quality And Waste Management. PhD Dissertation, Addis Ababa University, Ethiopia.

Omar, M., Hussain, H., Bhatti, G.A. and Altaf, M., 2013. Testing of random walks in Karachi stock exchange. Elixir Financial Management, 54, pp.12293-12299.

Tilahun, F., 2013. Performance of Poultry Marketing and Determinants of Market Participation: The Case of Smallholder Poultry Producers in Rural Kebeles of Dire Dawa Administration, Ethiopia (Doctoral dissertation, Haramaya University).

USDA (United States department of agriculture). (2013): International egg and poultry report.

Van Nostrand Rein Hold Company, 2016. Livestock and Meat Marketing, third Edition, Published by, New York, U.S.A, $p 8$

Vernooij, A.G., Cornelissen, J.M.R., Claassen, I.J.T.M., Beitler, E., Rees, H.L., Giani, A. and Cloezeman, S., 2012. Poultry in Ethiopia: a survey of production, value chain and marketing of commercial poultry in Ethiopia. Netherlands-African Business Council.

World Health Organization, 2011. World health statistics 2010. Geneva, Switzerland; 2010. http://www. who. int/whosis/whostat/2010/en/index. html, 38, p.39. 